\title{
キラルリン酸触媒の開発
}

\section{Development of Chiral Phosphoric Acid Catalyst}

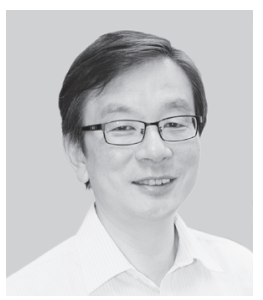

秋山 隆彦 (学習院大学理学部)

Takahiko Akiyama

我々は, 2004 年に, $(R)$-BINOL 由来の環状キラルリン 酸ジエステル(以下 キラルリン酸)1(図 1)が, Mannich 型反応において，キラルブレンステッド酸として優れた 不斉触媒能を示すことを報告した。キラルリン酸は, 瞬 く間に世界中に広がり，非常の多くの研究者がリン酸お よびリン酸誘導体を用いた不斉触媒反応の開発を報告し ている。本稿では, キラルリン酸の開発の経緯について 紹介する。

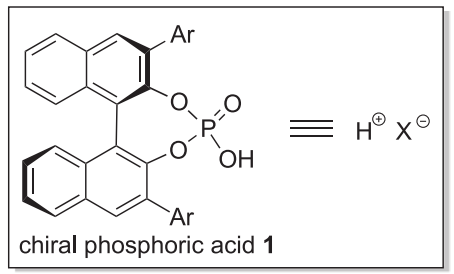

Fig. 1 Chiral phosphoric acid.

\section{1. イミンの選択的活性化反応}

筆者は, 大学院時代に， $(S)$-プロリン由来のキラルジ アミンを不斉配位子として用いた不斉反応の研究におい て，多段階を経て種々のキラルジアミンを合成したが, それ以外では含窒素化合物はあまり扱ってこなかった。 大学院卒業後, 3 年間余り塩野義製薬株式会社の研究所 に勤務し, $\beta$-ラクタム系抗生物質の合成研究に従事し, 多数の含窒素化合物を合成した。窒素原子が入った化合 物に, ルイス酸触媒を用いた反応を試しても，予期した 反応が進行しないことが多く，含窒素化合物と窒素を含 まない有機化合物との反応性の違いを感じていた。塩野 義製薬から愛媛大学に移ってからも, 含窒素化合物の合 成に役立つ反応の開発に関心を持っていた。

そのような状況の中で, 1994 年に学習院大学に赴任

学習院大学理学部(171-8588 東京都豊島区目白 1-5-1)

Department of Chemistry, Gakushuin University(1-5-1 Mejiro, Toshima-ku, Tokyo 171-8588)
したのちに，アルデヒド $(\mathrm{RCHO})$ とアルドイミン $(\mathrm{RCH}$ =NR')のどちらの反応性が高いのだろうかと考えた? もちろんイミンの窒素上の置換基により反応性は大きく 変化するので一義的に決めることは困難であろう。学生 時代には大まかに，ルイス酸を用いた反応では，イミン は比較的反応性が低いと教わっていた。1996 年に山本, 中村(東北大)らは国，アリルスズ化合物を用いたアリル 化反応において $\mathrm{Pd}(\mathrm{II})$ 錯体を用いることで, 一方, 1997 年に小林 (東大) らは ${ }^{1 \mathrm{~b}, \mathrm{c})}$ シリルエノラートの付加反 応およびアリルスズ化合物を用いたアリル化反応におい て $\mathrm{Yb}(\mathrm{OTf})_{3}$ を用いることにより，アルデヒド存在下ア ルドイミンが選択的に反応することを報告した。

我々は，このアルデヒドとイミンの反応性の差異に興 味を持ち, ルイス酸触媒を用いたシリルエノラートの求 核付加反応におけるアルデヒドとイミンの選択性を調べ ている中で, 微量の水を添加することにより, アルデヒ ド選択性からイミン選択性へと大きく変化することを見 出した(表 1) 2a)。

Table 1 Reactivity between aldimine and aldehyde.

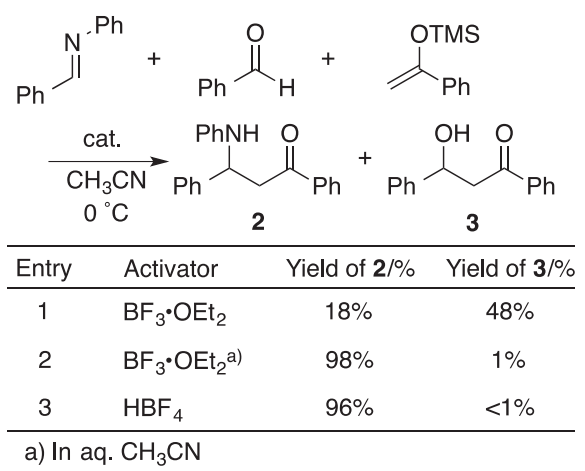

すなわち, $\mathrm{BF}_{3} \cdot \mathrm{OEt}_{2}$ を等量用いるとアルデヒドに対 する反応が優先し，アルドール付加体 3 が主生成物とし て得られる (entry 1)が, $\mathrm{BF}_{3} \cdot \mathrm{OEt}_{2}$ を触媒的に用いて微 量の水あるいはアルコール等のプロトン源を加えると, イミンに対する求核付加反応である Mannich 反応が優先 
して, Mannich 付加体 2 が極めて高い選択性で得られる ことがわかった。これは, $\mathrm{BF}_{3}$ と $\mathrm{H}_{2} \mathrm{O}$ から $\mathrm{H}^{+} \mathrm{BF}_{3}(\mathrm{OH})^{-}$ のようなブレンステッド酸が生成し, これが活性種とし て作用しているのではないかと考えた(スキーム1)。

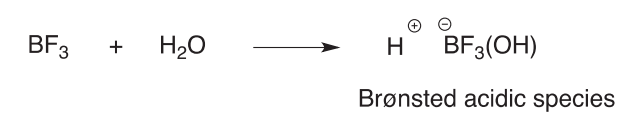

Scheme 1 Generation of Brønsted acidic species.

もしそうであれば，ルイス酸触媒の代わりにブレンス テッド酸を用いればイミン選択性が実現できるのではな いかと考えた。実際に種々の汎用ブレンステッド酸がイ ミン選択性を示し, $\mathrm{HBF}_{4}$ を用いた際に, 最も優れた結 果が得られた。すなわち, 遷移金属錯体やランタノイド トリフラート等の高価な錯体を用いなくても, 安価かつ 汎用的なブレンステッド酸で, イミン選択性が発現でき るのである。

さらに, このイミン選択性を活かして, 三成分連結型 の Mannich 型反応を開発した。ブレンステッド酸存在 下, 含水溶媒中 (conditions 1) あるいは, 界面活性化剂で SDS 存在下水中 (conditions 2) において, アルデヒド, アニリン, シリルエノラートを攪拌するのみで, 系中で 生成したイミンに対するシリルエノラートの Mannich 型反応が速やかに進行し， $\beta$-アミノエステルが良好な 収率で得られた $(ス キ ー ム 2 ~)^{2 b, c)}$ 。興味深いことに，含 水溶媒中あるいは, 水中において, アルデヒドとアニリ ンの脱水縮合反応が効率よく進行し，イミン付加体のみ が得られ，アルドール生成物は全く得られない。

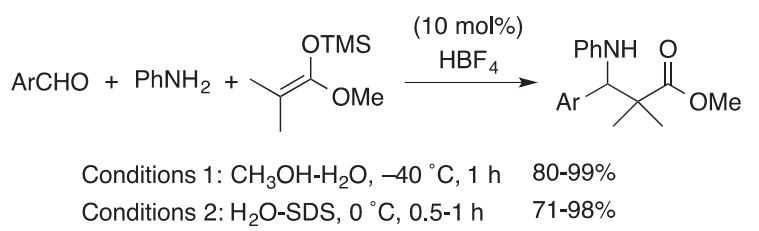

Scheme 2 Three-component Mannich-type reaction.

\section{2. キラルブレンステッド触媒の開発}

ブレンステッド酸がイミンの優れた活性化剤であるこ とを見出したので, キラルなブレンステッド酸を用いる ことで，この Mannich 型反応の不斉触媒化に着手した。

なお，キラルブレンステッド酸という概念に関して, すでに山本, 石原 (名大)らは, ルイス酸と BINOL を系中 で混合することによりブレンステッド酸性を示すことを 明らかにし, Lewis acid-assisted chiral Brønsted acid (LBA) という概念を提案しているが3), 単離可能で安定 な比較的強いキラルブレンステッド酸を用いた不斉触媒 反応は, 筆者が知る限り知られていなかった。
まず手始めに，窒素上に 0 -ヒドロキシ基の置換した アルドイミンとケテンシリルアセタールとの Mannich 型反応を試した。アルドイミンとしては, なにかしらの 官能基がある方が不斉の発現が容易であろうとの, 安易 な（？）考えで，Oーヒドロキシ基の置換したアルドイミ ンを用いた。これが, 結果的に功を奏した。

まず, 容易に入手可能なキラルブレンステッド酸として カンファースルホン酸を試したが, 全くエナンチオ選択 性は発現しなかった。とは言っても, カンファー骨格を 変換するのは容易ではないと考えられるので, 新たなキ ラルブレンステッド酸をデザインすることとした。

キラルブレンステッド酸がイミンを活性化すると，イ ミニウムイオン中間体が生成すると考えられる(図 2)。 この中間体を経て高いエナンチオ選択性を得るために, 以下の 2 つ仮説を立てて, キラルブレンステッド酸を デザインした。

1）ブレンステッド酸の酸性が強すぎると，イミニウム イオンは “loose”なイオン対となり, 対イオンの立体効 果が弱まる。そのため, 反応を促進するに十分な酸性度 を有する弱酸が好ましい。

2）環状構造を有する対アニオンが必要である。

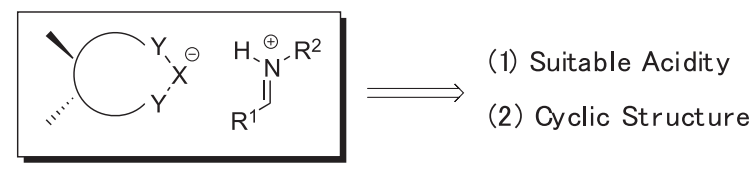

Fig. 2 Iminium ion intermediate.

そこで, BINOLを用いることを着想した。BINOL は BINAP などの不斉触媒と同様のビナフチル骨格を有し ていることから，良好な不斉場を提供することができ， また，二つのヒドロキシ基を利用して環状リン酸 1 とす れば, 容易にキラルなブレンステッド酸となると期待し た。

まず，3,3-位無置換のキラルリン酸 1a を用いてイソ 酪酸由来のケテンシリルアセタールとの反応を検討した

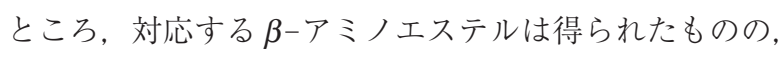
ラセミ体であった。この結果に落胆したものの, 3,3'-位 にフェニル基の置換したキラルリン酸 $1 \mathrm{~b}$ を用いると $\beta-$ アミノエステルが $24 \%$ ee で得られ大いに喜んだ!（ス キーム3)

これは, 我々にとって, 極めて重要な結果であった。 すなわち, リン酸のビナフチル基の 3,3-位に置換基を 導入することにより, 不斉誘起が実現できることを見出 した感動の瞬間である。今でこそ, 様々な置換基を有す るキラルリン酸が知られており, 研究室にストックして あるため, 置換基効果の検討は容易であるが, その時 は, 全てが新規化合物であり, 一つ一つを自分たちで合 

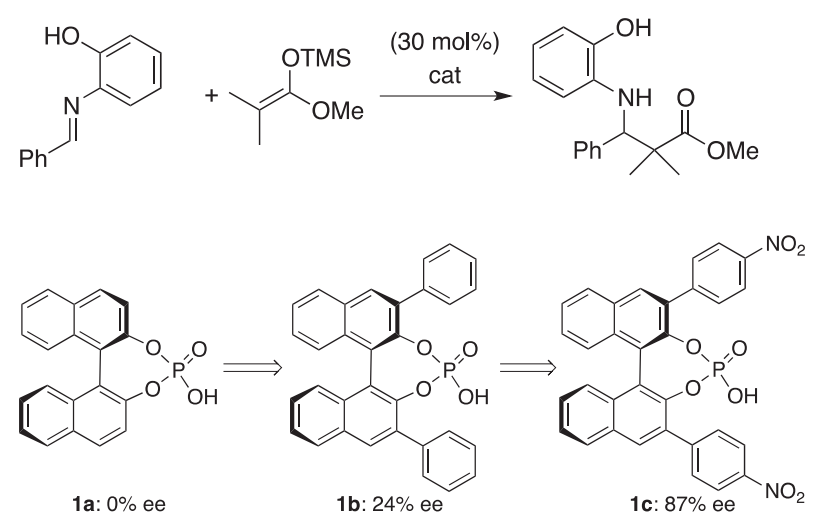

Scheme 3 Enantioselective Mannich reaction.

成する必要があった。また，3,3’位に置換したリン酸を 合成しても，不斉誘起が起こる保証はなく，進んで検討 してくれた伊藤博士 (当時修士課程学生)に改めて感謝し たい。

上述の結果に勇気を得て，3,3’位の置換基を種々検討 した。かなり時間を要したが, 最終的に4-ニトロフェ ニル基を導入すれば，不斉収率が $87 \%$ ee まで向上する ことがわかった。キラルリン酸 1c $(10 \mathrm{~mol} \%)$ を用いるこ とにより，種々のケテンシリルアセタールとイミンとの Mannich 型反応が効率よく進行し, 対応する $\beta$-アミ)

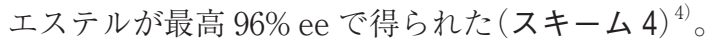

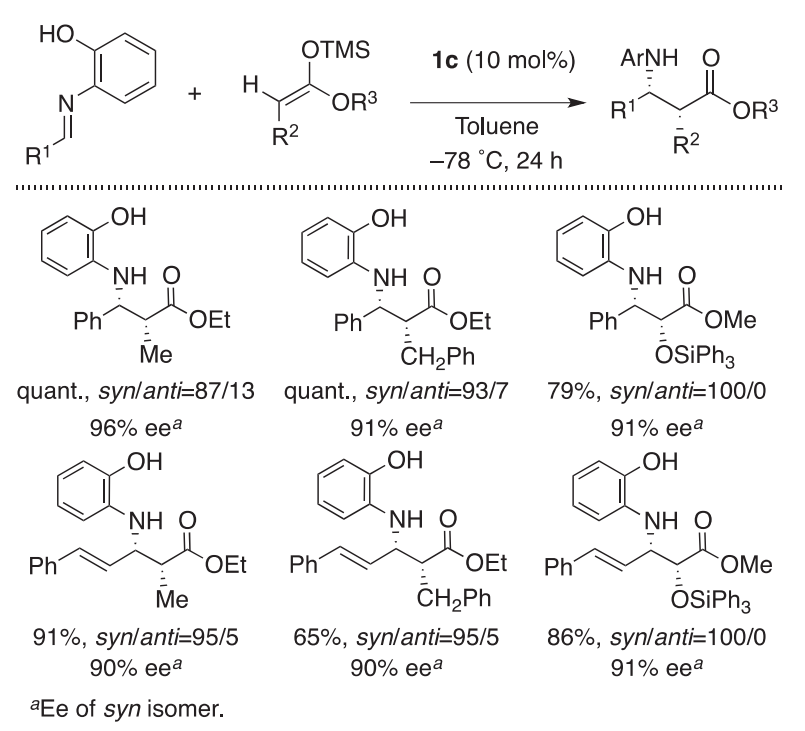

Scheme 4 Enantioselective Mannich-type reaction.

こうして得られた結果を論文にまとめアメリカ化学会 誌に投稿したが，全く評価されず，大いに失望した。し かしながら，その後, Angew. Chem. Int. Ed. には評価 いただき，めでたく掲載された。2003 年 11 月 3 日に投 稿が受理された後，わずか 10 日後の 11 月 13 日には provisional acceptance のメールを受け取ることができ たのはとても嬉しかった。なお， $O$-ヒドロキシ基の置換

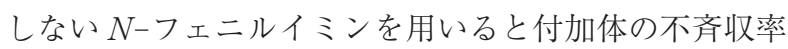

が大きく低下することから, 最初の原稿では 9 員環遷移 状態 4 を提案していたが, 審査員の一人から evidence を示すべきとの意見があり, いささか弱気になって無難 なイオン対 5 に書き換えた(図3)。

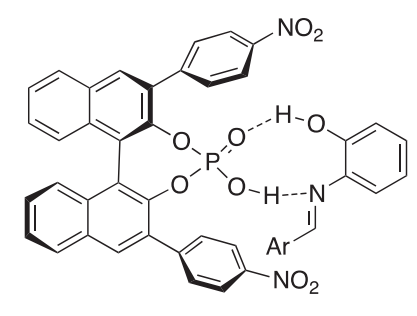

4

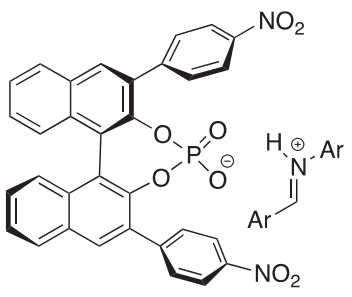

5
Fig. 3 Complex derived from phosphoric acid and aldimine.

その後, 山中らとの共同研究として理論化学計算を行 い, 当初予想していた 9 員環遷移状態が見出された時 は，とても嬉しかったことを鮮明に覚えている。キラル リン酸は，基本的にはキラルブレンステッド酸である が, ホスホリル基の酸素原子がルイス塩基部位として機 能するので総じて二官能性の触媒であると見なすことが できる $\left(\right.$ 図 4) ${ }^{5)}$ 。なお, その後の研究で, 3,3'-位の置換 基は，立体選択性のみならず反応性にも大きな影響を与 えていることが明らかになった。

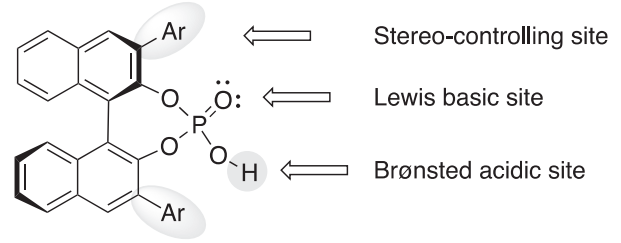

Fig. 4 Function of chiral phosphoric acid.

キラルリン酸を用いた不斉触媒反応は, 我々の発表と ほぼ同時期に, 寺田(東北大)らによっても独自に報告さ れた ${ }^{6)}$ 。つのグループから一挙に報告されたことが, 世界中でより注目されることにつながったと考えられる。 2005 年 3 月に Benjamin List (Max-Planck 研究所, ド イツ)を東京に招へいした。当時 List は, プロリン誘導 体を不斉触媒として用いた触媒反応の開発を精力的に 行っており，また世界中で数多くのプロリン触媒反応が 報告されていた。List は,「キラルリン酸は将来的にプ ロリンと同様の状況になるよ。また君の人生も大きく変 わるよ」と言っていた。当時はその言葉を信じることが できなかったが, その後, 膨大な数のキラルリン酸を用 いた不斉触媒反応の報告がなされ，その予言が現実のも のとなった ${ }^{7)}$ 。そもそも, List 自身が現在最も活発にキ ラルブレンステッド酸を用いた研究を行っている。List は我々のAngew. Chem.の論文を読み, イオン対 5 の 構造を見て「これは面白い, この概念は広く使える」と直 
感したそうだ。

キラルリン酸は, キラルブレンステッド酸としてイミ ンの活性化に有効であることを見出したが，その後，イ ミンのみならずアルデヒド, ヒドロキシ基, アルケン等 様々な官能基の活性化にも用いられることが見出されて いる。ブレンステッド酸は，基本的に汎用性の高い触媒 であり，キラルブレンステッド酸は，不斉認識や分子認 識等を併せ持つブレンステッド酸であり, 今後も更に多 くの不斉触媒反応に展開できると考えられる。更に，キ ラルリン酸は, キラルブレンステッド酸としてのみなら ず, キラル対アニオン, さらにはキラルリン酸金属塩と しても幅広く用いられており，極めて多くの反応の優れ た不斉触媒として機能することが明らかになっている。

なお, キラルリン酸の化学についての詳細について は, 2005 年, 2011 年, および 2017 年に有機合成化学協 会誌に総合論文を発表済みであるので，ご参照いただき たい ${ }^{8)}$

本研究は, 鷹谷絢博士 (現 東京工業大学准教授), 伊 藤淳二博士(現 アステラス製薬(株)), 神子島博隆助教 (現 茨城大学准教授), 㴊辺耕平助教(現 筑波大学准教 授）を始めとする多くの共同研究者の努力の賜物である。 ここに感謝します。

\section{文 献}

1) (a) H. Nakamura, H. Iwama, Y. Yamamoto, J. Am. Chem. Soc., 118, 6641 (1996); (b)S. Kobayashi, S. Nagayama, J. Org. Chem. 62, 232(1997); (c)S. Kobayashi, S. Nagayama, J. Am. Chem. Soc., 119, 10049 (1997)

2) (a) T. Akiyama, J. Takaya, H. Kagoshima, Chem. Lett., 28, 947 (1999); (b) T. Akiyama, J. Takaya, H. Kagoshima, Synlett, 1999, 1045; (c) T. Akiyama, J. Takaya, H. Kagoshima, Synlett. 1999, 1426

3) (a) K. Ishihara, M. Kaneeda, H. Yamamoto, J. Am. Chem. Soc., 116, 11179(1994); (b)H. Yamamoto, K. Futatsugi, Angew. Chem. Int. Ed., 44, 1924(2005)

4) T. Akiyama, J. Itoh, K. Yokota, K. Fuchibe, Angew. Chem. Int. $E d ., 43,1566(2004)$

5) M. Yamanaka, J. Itoh, K. Fuchibe, T. Akiyama, J. Am. Chem. Soc., 129, 6756(2007)

6) D. Uraguchi, M. Terada, J. Am. Chem. Soc., 126, 5356(2004)

7) (a) T. Akiyama, Chem. Rev., 107, 5744(2007); (b) D. Parmar, E. Sugiono, S. Raja, M. Rueping, Chem. Rev., 114, 9047 (2014); (c) D. Parmar, E. Sugiono, S. Raja, M. Rueping, Chem. Rev., 117, 10608(2017)

8）(a)秋山隆彦，㴊辺耕平，伊藤淳二，有機合成化学協会誌，63, 1062 (2005); (b) 秋山隆彦, 有機合成化学協会誌, 69, 913 (2011); (c)秋山隆彦，有機合成化学協会誌，75，410(2017)

(2019 年 6 月 12 日受理)

\section{PROFILE \\ 秋山隆彦 学習院大学理学部・教授 理学博士 〔経歴〕1985 年 3 月東京大学大学院理学系研究科化学専門課程博士 課程修了, 1985 年 4 月塩野義製薬株式会社研究所, 1988 年 7 月愛 媛大学工学部助手, 1994 年 4 月学習院大学理学部助教授, 1997 年 4 月より現職。1 992 年 4 月 -93 年 3 月米国 Stanford 大学博士研究 員。〔専門〕有機合成化学。〔連絡先〕 e-mail: takahiko.akiyama@ gakushuin.ac.jp}

